\title{
Rainwater Harvesting in Buildings in Brazil: A Literature Review ${ }^{\dagger}$
}

\author{
Enedir Ghisi, Barbara Müller Colasio, Matheus Geraldi and Andrea Teston* \\ Laboratory of Energy Efficiency in Buildings, Department of Civil Engineering, Federal University of Santa \\ Catarina, 88040-900 SC Florianopolis, Brazil; enedir@labeee.ufsc.br (E.G.); \\ barbara.colasio@gmail.com (B.M.C.); matheus.s.geraldi@gmail.com (M.G.) \\ * Correspondence: andreateston@yahoo.com.br; Tel.: +55-48-3721-5184 \\ + Presented at the 2nd International Electronic Conference on Water Sciences, 16-30 November 2017; \\ Available online: http://sciforum.net/conference/ecws-2.
}

Published: 16 November 2017

\begin{abstract}
This article presents a literature review of rainwater usage in buildings in Brazil. It focuses on economic, environmental, and social impacts. The legislation related to rainwater harvesting-including the cities that have made such a practice mandatory-was also assessed. The literature review was based on a search strategy that uses protocols to find and select studies about the main subject, i.e., rainwater harvesting in buildings. The protocols were defined as the site to be investigated (buildings), the intervention (rainwater harvesting), and the expected result (influence on the potable water consumption). Despite the variation of water availability in the country, it was concluded that there is a high potential for potable water savings when using rainwater in buildings in Brazil. Finally, it was observed the need for financial investments in experimental research and innovation technologies in order to improve rainwater management.
\end{abstract}

Keywords: rainwater usage; potable water savings; investment feasibility analysis; urban flood mitigation; sustainable urban water systems; public policy; water conservation; buildings; Brazil

\section{Introduction}

For approximately two centuries, water management in cities followed the principles of control and domination, which are well represented by urban drainage, which is sized so that the urban environment is free of floods [1]. With the continuous urbanization process, larger drainage systems are required [2], which increasingly interfere with the natural cycle of water. The main impacts of urbanization on the water cycle are the increase in runoff and the anticipation of peak flows, the reduction of evapotranspiration and groundwater supply, and the deterioration of surface water quality [3].

In addition, the concern about water shortage is a target for studies all over the world, in local level [4-6], mostly in regions that already suffer from lack of water, and on a global level [7-10]. Kummu et al. [10] demonstrated that while water consumption increased fourfold in the 20th century, the population suffering from water scarcity rose from 0.24 billion (14\% of the world population) in the 1900s to 3.8 billion (58\%) in the 2000s. Vörösmarty et al. [9] pointed that almost $80 \%$ of the world population is exposed to high levels of threat to water safety.

Another issue is about the losses of treated water in cities. Worldwide, the average water loss is $35 \%$, and in Brazil it is close to $40 \%$ [11]. According to the Brazilian Diagnosis of Water and Sewage Services of 2015, the national average water loss is $36.7 \%$ [12], i.e., in addition to wasting potable water, this index represents a high waste of energy. According to Gomes [13], the energy consumption of water and sewage service providers represent about $3 \%$ of the total energy consumption in the world. 
From this perspective, there is a need to seek a balance in the hydrological cycle in cities, hence the current model of water and sanitation urban services need to undergo changes [14]. The water industry has been seeking for alternatives for the sustainable planning of services provided $[15,16]$. Among such alternatives are the increase and maintenance of permeable areas and the use of decentralized water systems [17], such as rainwater harvesting systems.

The great climatic differences all over Brazil hinder the water management. Despite having high rainfall levels in almost all of its territory, which guarantees water to supply the cities, rainwater is considered as a source of water only in regions where water is scarce, such as the Brazilian semi-arid region. In such regions, social programmes encourage rainwater usage for surviving purposes. In other cities, rainwater harvesting is considered as advancement in technology and constructive methods [18]. Besides, the perception of the benefits of using rainwater in buildings is small when compared to its potential, because legislations and incentives for rainwater harvesting in buildings are still few and recent [19].

Even though there are records of rainwater harvesting over thousands of years [20], new technologies for rainwater harvesting systems in buildings have been the subject of research in many countries in the lasts decades. One of the main reasons for the adoption of rainwater harvesting systems in buildings is the potential for potable water by using rainwater where there is no need for potable water.

Overall this article presents a literature review of scientific studies that have been developed in Brazil regarding rainwater usage in buildings. The evolution of public policies on rainwater is also assessed. Thus, this paper presents the state of the art on rainwater and how it has evolved in Brazil, demonstrating the trending of the studies developed, future perspectives, and a comparison to studies developed abroad.

\section{Methods}

The literature review was based on a strategy that defined the main subject through the site to be investigated (buildings), the intervention made (the rainwater usage), and the expected result (the influence of intervention on the consumption of potable water). Through this strategy, the key question of the research was: "What is the potential for potable water savings through the installation of rainwater harvesting systems in buildings?"

First, a portfolio of studies related to the rainwater utilization system was obtained from CAPES (an agency of the Brazilian government for postgraduate studies), which keeps a website with doctorate's theses and master's dissertations published in Brazil, covering a period of ten years (2007-2017). The studies were identified focusing on the subareas "environment", "engineering", and "earth sciences". In Brazil, the researches present differentiated nomenclatures, due to the synonyms of words like "pluvial" and "rain". Therefore, the search protocols used were:

- Protocol 1: Utilization AND water AND (pluvial OR rain);

- Protocol 2: Utilization AND water AND (pluvial OR rain) AND (domest * OR residenc * OR edifica *); and

- $\quad$ Protocol 3: Utilization AND water AND (pluvial OR rain) AND (domest * OR residenc * OR edifica *) AND drinkable.

The studies on rainwater harvesting systems were identified, and the most relevant researches with possibility of comparison of results were selected. In addition, a search was made in national scientific journals and conferences related to water resources and sustainable constructions.

Papers published in international journals were also selected. Equivalent research protocols were used for researching in Portuguese and English, in order to allow an equivalent comparison. The purpose of this search was to compare the national scientific production with the international production in order to assess if the national production follows the pace of the international studies, quantitatively and temporally. 
After the selection of studies, they were reviewed from a meta-analysis, allowing a view of the general panorama. In the sequence, the works were filtered according to the topics of interest and allocated in each research topic.

\section{Results}

\subsection{Brazilian Production}

By searching theses and dissertations, Protocol 1 resulted in 151 works, i.e., 127 dissertations and 24 theses. However, many of these works were not related to the focus of our search; Protocol 2 presented more coherent results, showing 59 works (48 dissertations and eleven theses), and it was used to develop this search; Protocol 3 filtered the searches to make sure all works were consistent with the subject under investigation. Therefore, 34 works were found, being 29 dissertations and five theses.

Thus, the reviewed theses and dissertations related to the topic, selected through Protocol 2, were developed on the subjects presented in Table 1 . However, from the titles presented by the search protocol, eight were not found in their entirety and seven were inconsistent with the intended subject.

Table 1. Subjects covered by the theses and dissertations obtained from Protocol 2 and considered in our review.

\begin{tabular}{ll}
\hline Subject & References \\
\hline Water quality and health risks & {$[21-35]$} \\
Social acceptance & {$[36]$} \\
System measurements and its variables & {$[23,24,28,33,37-45]$} \\
Potential for saving potable water & {$[29,31,43,46-49]$} \\
Economic viability & {$[36,46,50-55]$} \\
Environmental impact & {$[54,56]$} \\
Impact on drainage & {$[39,57,58]$} \\
Different typologies of surface runoff harvesting (quality and quantity of water collected) & {$[59-61]$} \\
Literature review & {$[62-64]$} \\
\hline
\end{tabular}

Although the theses and dissertations have been classified in these large groups, not all of them present results that can be compared, since there is a great variety of topics researched within these groups, such as the method used for evaluation, for example. Most of the thesis and dissertations selected focus on water quality and health risks, the design of the system and its variables, the potential for potable water savings, and economic viability.

Regarding water quality, however, there are no standard parameters that have been investigated for potable and non-potable purposes. In this way, it is difficult to compare different research papers, since they analyse different parameters. Regarding the rainwater system, with the exception of some studies that evaluated the influence of the variables in the system [37,44], most of them proposed different methods for rainwater tank sizing or compared the methods proposed by the Brazilian Standard for Rainwater Usage. The potential for potable water savings is influenced by the tank sizing method used in the research, which also makes it difficult to compare the results. The same is true for the economic viability. It is worth mentioning the research carried out by Leon [55], which was concerned with accounting for the sewage generated by the rainwater harvesting system in the cost of disposal and treatment of sanitary sewage, which is generally not accounted for.

Regarding the other subjects, such as drainage and environmental impact, little research were found, which demonstrates the need for further studies in this area. According to Ghimire et al. [65], implementation of rainwater systems continues to be a challenge, mainly due to a lack of understanding of their environmental and human health impacts (material selection criteria and energy use) and partly due to a lack of regulations to which systems are governed. To prove the effectiveness of the systems in minimizing environmental impacts, it is necessary to use evaluation tools, allowing the benefits to be analysed holistically. 
Regarding the evolution of subjects over the years, it was not possible to establish a trend line of decrease or growth in the number of theses and dissertations. In the second search protocol, which was the most coherent for this review, the average number of studies developed each year was 5.4. The year that presented the highest number of works was 2012, i.e., seven dissertations and one thesis.

In order to analyse whether national production follows the pace of international studies, quantitatively and temporally, Figure 1 shows the number of academic researches published in Brazil and papers published abroad over 2007-2017.

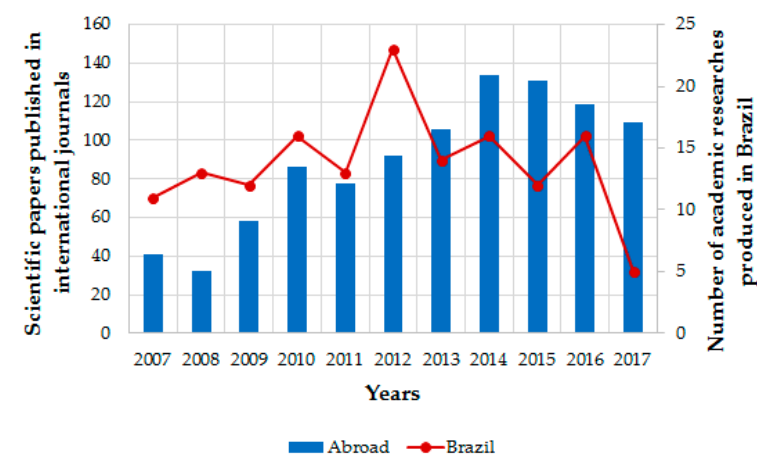

(a)

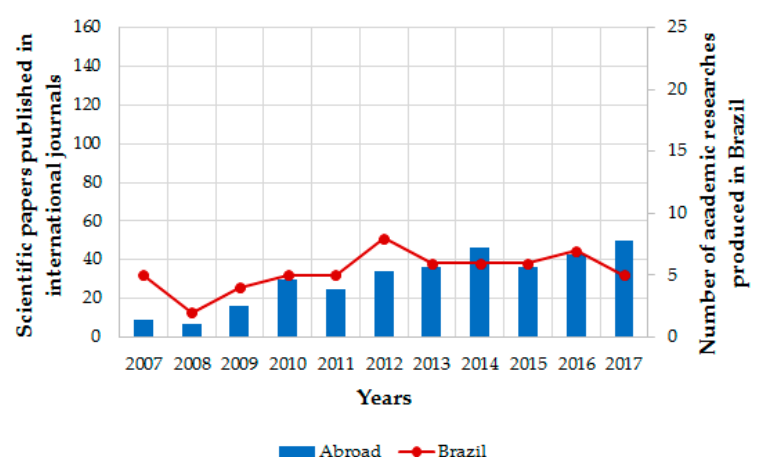

(b)

Figure 1. Number of scientific publications in Brazil and abroad found through the search protocols (a) Protocol 1: Utilization AND water AND (pluvial OR rain); and (b) Protocol 2: Utilization AND water AND (pluvial OR rain) AND (domest * OR residenc * OR edifica *).

It can be seen that national production is generally smaller than international production. However, it grows accordingly. There has been growth of international works in this area since 2009, and this growth has been noticeable in national production related to buildings, which reveal that the Brazilian scientific scenario worries not only about restricting rainwater usage to mitigating extreme drought problems, but also as an alternative water source to be used in buildings to provide financial savings and reduce environmental impact.

There are papers written by Brazilian researchers that were published in international journals. These papers were classified as scientific papers published in international journals (abroad). However, by reviewing the publications it was noticed that many researchers do not publish results obtained in their theses or dissertations in international journals, which results in low or no citation of their works. Considering that science evolves according to each research carried out, this factor delays the evolution of the national surveys.

\subsection{Potential for Potable Water Savings}

As for rainwater harvesting for non-potable purposes, many papers related to the potential for potable water savings [66-71] were found. The potential for potable water savings is closely related to the water end-uses. Thus, some researchers have been developing research on the water end-uses in residential buildings [56,72-79], schools [80,81], hotels [82], office buildings [83], and public administrative buildings [84]. The average, minimum, and maximum non-potable uses are shown in Figure 2.

In addition, the potential for potable water savings depends on rainfall, area, and type of surface to collect rainwater, rainwater demand, and potable water demand. Thus, a better way of sizing the rainwater tank is by means of computer simulation that takes into account daily rainfall and daily water demand [85]. Considering a great variability of the rainfall time series used in the research, some researchers have evaluated the influence of the time series length on the rainwater harvesting systems sizing [68,86]. Geraldi and Ghisi [86] used a 30-year time series from Berlin, Germany, as a reference and then compared the results with those of shorter series. It was observed that the shortest rainfall time series length that satisfies the proposed criteria was ten years. 


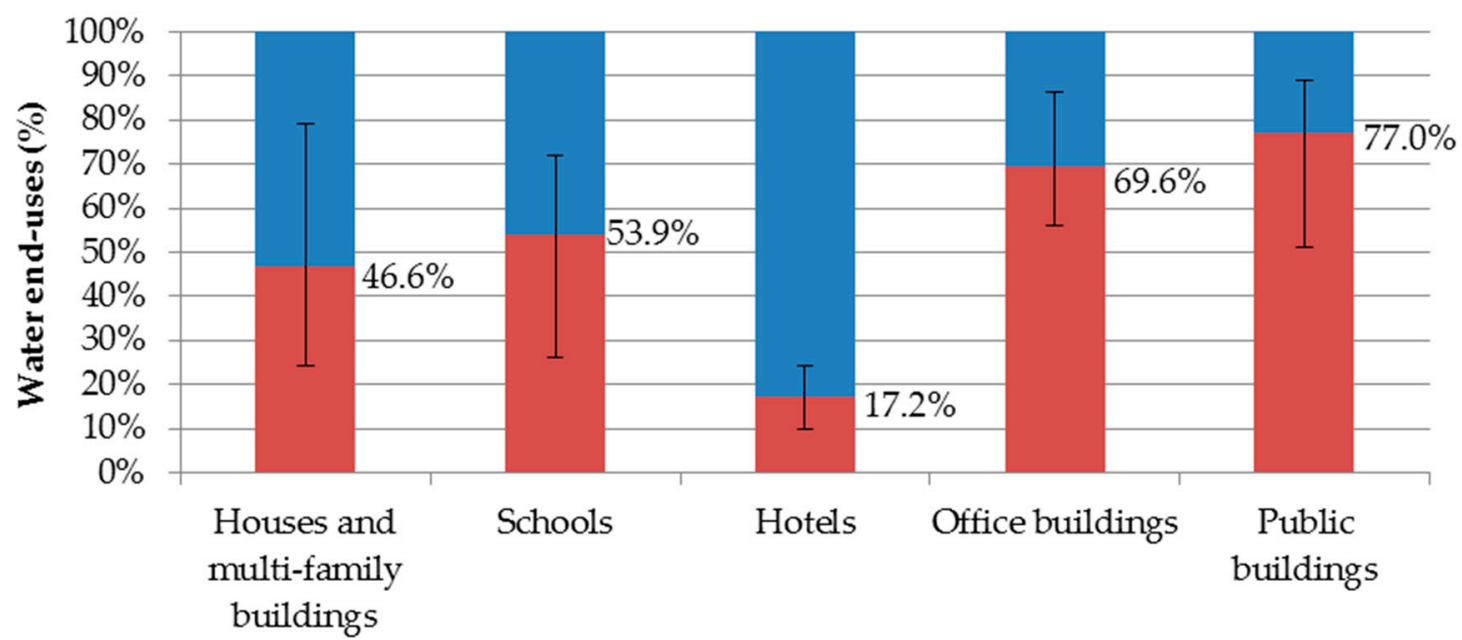

non-potable uses $\quad$ Potable uses

Figure 2. Potable and non-potable water end-uses in different types of buildings in Brazil.

Although the Brazilian standard on rainwater usage in buildings presents six methods for tank sizing, there are criticisms about them, such as the fact that the results presented by them are very different from each other [87]. According to Dornelles [39], the practical methods in the standard are those that present greater limitations, since they adopt ratios of simple proportionality between rainfall and tank capacity, i.e., they do not take the seasonal behaviour of rainfall into account. Thus, there are recommendations in the literature about the use of the computer programme Netuno [70,88-90], developed in the Laboratory of Energy Efficiency in Buildings of the Federal University of Santa Catarina. Netuno estimates the volume of rainfall that can be used daily, the volume of rainwater available in the tank before consumption, the volume of rainwater consumed in a day, and indicates the ideal tank capacity through a predetermined interval between volumes $\left(\mathrm{m}^{3}\right)$ and an index of potential differences of potable water $\left(\% / \mathrm{m}^{3}\right)$. Thereby, it is possible to obtain the potential for potable water savings [91].

Other parameters can also be evaluated to determine the system performance, such as reliability and efficiency. As per Bezerra et al. [87], reliability is the relationship between the period in which demand is met with rainwater and the total investigated period, and efficiency is the relationship between the volume of harvested rainwater and the volume of rainwater that did not overflow from the tank. Therefore, reliability is related to the verification of the service to the demand, and efficiency is related the impact of the rainwater harvesting system on runoff.

Teston et al. [85] compiled nine national research papers on the potential for potable water savings through the use of rainwater in residential buildings and obtained results for 158 cases. Using this compilation, when it comes to residential buildings, Figure 3 shows the frequency of rainwater demand (a), potable water savings (b), and system reliability (c). 


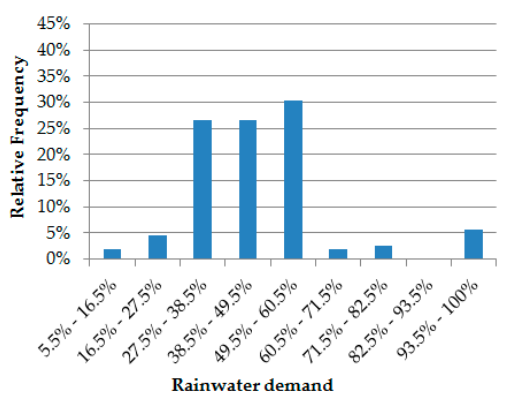

(a)

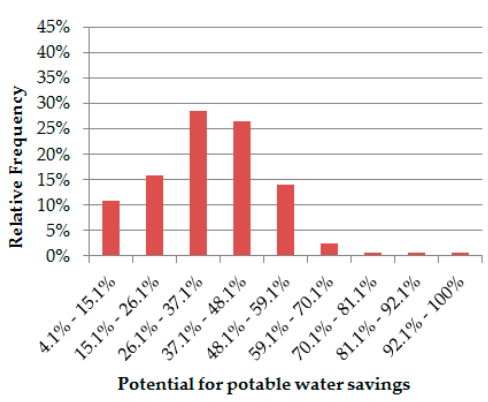

(b)

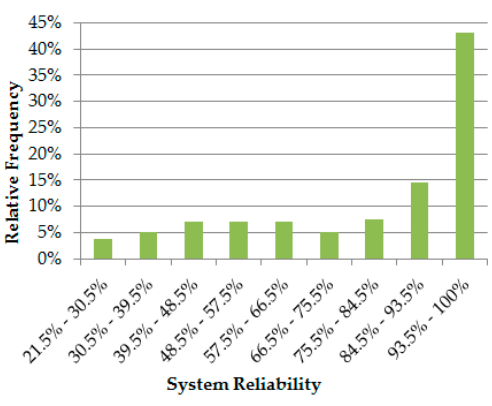

(c)

Figure 3. Histograms of (a) rainwater demand, (b) potential for potable water savings, and (c) system reliability, resulting from research data on rainwater harvesting in residential buildings obtained from $[66,67,72-74,78,79,92,93]$.

Through Figure 3, it is possible to notice that most of the surveys considered rainwater demand from $27.5 \%$ to $60.5 \%$, due to the non-potable water end-uses. Only about $5 \%$ of the investigated cases adopted rainwater demand of $93.5 \%$ to $100 \%$; of these, only $1 \%$ met such a demand. More than $55 \%$ of the cases obtained potential for potable water savings from $26.1 \%$ to $48.1 \%$. Marinoski et al. [94] obtained similar results when evaluating twenty houses in southern Brazil. Non-potable uses accounted for, on average, $33 \%$ of the total water consumed. By using rainwater, considering a 3000 -litre rainwater tank estimated by Neptune, the potential for potable water savings was $30 \%$ (Reliability of $90 \%$ ). Using a 10,000-litre tank, this potential would reach $33 \%$, that is, it would have $100 \%$ reliability, taking into account all the demand.

In Figure 3, it is also observed that more than $40 \%$ of the investigated cases obtained reliability from $93.5 \%$ to $100 \%$, and reliability remained above $75 \%$ in about $65 \%$ of cases. Considering the variability of the data used in the research (varying rainfall, roof area, and water demand), it can be concluded that the systems meet the demand for rainwater in residential buildings satisfactorily.

Marinoski and Ghisi [80], Fasola et al. [81], and Salla et al. [95] evaluated the impact of rainwater harvesting on potable water consumption in schools. Marinoski and Ghisi [80] evaluated a school in Florianópolis and considered rainwater demand ranging from $48.5 \%$ to $78.5 \%$. Fasola et al. [81] considered two case studies, being a municipal school and a state school. Salla et al. [95] evaluated several results in a university, considering different number of students and rainwater demands. Considering the results obtained by the authors, Figure 4 shows the frequencies of rainwater demand (a), potable water savings (b), and reliability (c).

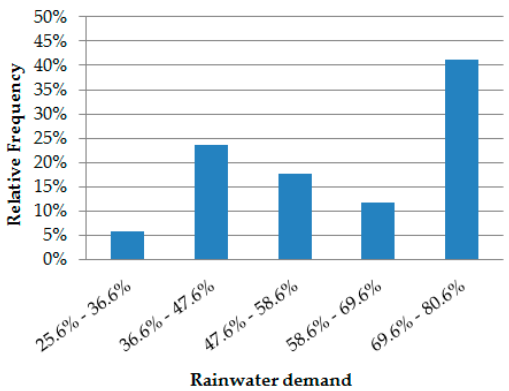

(a)

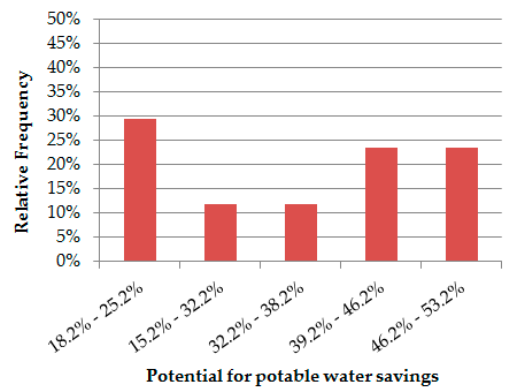

(b)

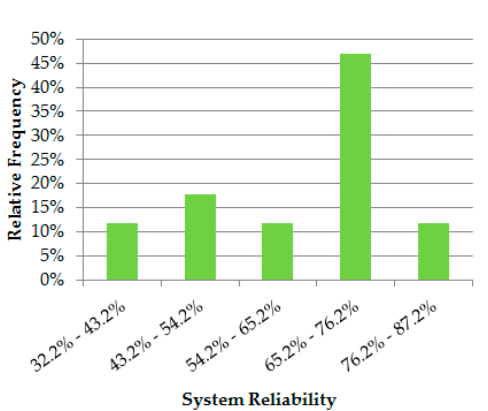

(c)

Figure 4. Histograms of (a) rainwater demand, (b) potential for potable water savings, and (c) system reliability, resulting from research data on rainwater harvesting in schools obtained from $[80,81,95]$.

It is noted that, although more than $40 \%$ of the data adopted rainfall demand in the range of $69.6 \%$ to $80.6 \%$, the highest value for a potential of potable water saving was $53.2 \%$. When analysing the reliability of the system, it is observed that demand is met more than $65 \%$ of the time with a frequency of approximately $60 \%$. However, only $11 \%$ of the data showed reliability above $76 \%$. This is mainly due to the high demand for rainwater. The monthly rainwater demand in the buildings 
analysed by the authors varies from 32,783 litres per month to 338,400 litres per month. The reliability of the system with the lowest monthly rainwater demand is $87.7 \%$, while reliability is only $31.5 \%$ for the building with the highest rainwater demand.

It is not possible to obtain, through these case studies, a simplified relationship between system reliability and rainwater demand because the potential for potable water saving is influenced by other variables, such as rainfall and roof area. Silva and Ghisi [96] performed a sensitivity analysis of design variables and an analysis of uncertainties of daily potable water demand in the performance of rainwater harvesting systems. The dependent variables analysed were the potential for potable water savings and the design of the underground tank capacity for some cities with different rainfall levels. In general, design variables such as daily potable water demand, rainwater demand, and roof area were the most influential in assessing the ideal underground tank capacity and potential for potable water savings. Rainwater demand was the most influential variable in the potential for potable water savings for most cities analysed. The uncertainty in ideal underground tank capacity could be as great as 13,000 L. The use of an average value of potable water demand for performance evaluation of rainwater harvesting systems still generates uncertainties; however, it can be overlooked, because most of the considerable uncertainties had a low probability of occurrence.

Lopes et al. [71] evaluated the potential for potable water saving in residential buildings in 60 cities of Santa Catarina state, varying the roof area, the potable water demand, the rainwater demand, and the number of inhabitants per residence. They obtained some conclusions: the larger the roof area and the daily demand of rainwater, the greater the potable water saving and the ideal rainwater tank capacity; for small roof areas, the relationship between the increase in the daily rainwater demand and the ideal rainwater tank capacity is not linear; cities and regions with higher rainfall tend to require lower rainwater tank capacity and result in greater potable water savings; and cities with high rainfall variation throughout the year tend to need a larger ideal rainwater tank capacity, while cities with more uniform rainfall tend to require smaller rainwater tank capacity.

Ghisi et al. [88] assessed the potential for potable water saving through the rainwater usage for vehicle washing. For this, they varied the roof area, water demand, and tank capacity values, obtaining results between $9.2 \%$ and $57.2 \%$ of potential savings. When assessing the same purpose, Lage [97] concluded that with feasible and attractive investments, it is possible to obtain a potential for potable water saving between $9.7 \%$ and $26.8 \%$. The difference between the two studies was that Ghisi et al. [88] varied the data from the case study, with the intention of obtaining a relationship between the variables and Lage [97] simulated the design for the buildings of six case studies, without varying data such as roof area or demand.

It is noticed that, through the studies presented, there is great potential for potable water saving through the rainwater harvesting for non-potable purposes in buildings and also for washing vehicles.

\subsection{Economic Feasibility and Other Benefits}

The economic feasibility of a rainwater harvesting system is one of the determining factors for the implementation of this system. Your analysis should be performed to allow for decision making [98]. In view of this, many studies assess this viability through the payback on investment.

In the study done by Ghisi and Ferreira [72], applied in a multi-family building composed of three blocks in Florianópolis, Santa Catarina, the authors estimated the payback when implementing three scenarios with different systems: one of rainwater use, one of greywater reuse, and one considering both systems for rainwater usage and greywater reuse together. For the rainwater harvesting system, block A presented a payback equivalent to 2.4 years, block B at 5 years, and for block $C$ the payback was not estimated, because the water consumption was less than $10 \mathrm{~m}^{3}$. This 10 $\mathrm{m}^{3}$ is equivalent to the minimum water tariff to be charged by the concessionaire. This means that even if the building consumes less than $10 \mathrm{~m}^{3}$, there will be no reduction in the tariff charged for water consumption.

Ghisi and Oliveira [99] estimated the payback when considering the rainwater usage and the greywater reuse in two single-family residences in Palhoça, Santa Catarina. The payback for the 
rainwater harvesting system for residence $A$ was 21 years and 5 months, and for residence B it was 67 years and 4 months. The paybacks were recalculated considering the method of net value with interest rates of $1 \%, 5 \%$, and $10 \%$ per annum, increasing to 25 years (residence $\mathrm{A}$ and rate of $1 \%$ per annum) and 116 years (residence $B$ and rate of $1 \%$ per annum). For rates of $5 \%$ and $10 \%$ a year, both residences $\mathrm{A}$ and $\mathrm{B}$ had a payback greater than 250 years. Thus, the implantation of a rainwater harvesting system in this study was economically infeasible.

Júnior, Dias e Gadelha [100] considered three types of residences with distinct socioeconomic levels (popular, medium, and high standard) in João Pessoa, Paraíba, in their study about the economic feasibility of the rainwater harvesting system implementation. However, due to the low water tariff for the popular and medium standard residences, this system proved to be infeasible in these cases. In high-standard residences, in which water tariff and rainwater demand are higher, a positive economic feasibility was achieved for the implementation of the system, with payback periods ranging from 8.2 years to 10.2 years. When considering future scenarios with an increase in water tariff for residences of popular and medium standard, the installation of the rainwater harvesting system may become economically feasible.

Carvalho [101] estimated the economic feasibility of the rainwater harvesting system implantation in residential buildings in Londrina, Paraná. It considered a residence of $200 \mathrm{~m}^{2}$ with four inhabitants and water consumption of $R \$ 5.40 \mathrm{~m}^{3} /$ month. The savings obtained by using rainwater would be $R \$ 59.40$ per month, and the payback of the investment equivalent to 5 years and 3 months, which makes the implementation of the system economically feasible.

Ghisi and Schondermark [102] evaluated the economic feasibility of the implantation of rainwater harvesting systems in residences of five cities in Santa Catarina. In most of the analysed cases, were obtained paybacks between 1.5 and 10 years. However, in some cases, the paybacks ranged from 10 to more than 30 years.

Berwanger and Ghisi [103] carried out an economic feasibility analysis of the use of rainwater in the residential sector of Itapiranga, Santa Catarina. The authors performed simulations considering four residences and twelve variables for each residence. There was a high variation of the payback for the cases studied (from 8 years to periods greater than 20 years). Therefore, only cases that remained between 8 and 20 years were considered feasible, and cases with payback above 20 years were considered economically infeasible.

Cruz and Blanco [104] evaluated the rainwater usage for non-potable purposes in a single-family residence in Rio Branco, Acre. When considering eight inhabitants in the residence, the payback was 24 years, and when considering five inhabitants, the payback was 27.1 years. However, when comparing with the city of Belém, Pará, changing the value of the water tariff from $R \$ 1.99$ to $R \$ 2.68$, the payback decreases to 17.9 years for eight inhabitants and 20.1 years for five inhabitants. The system proved to be infeasible due to the high payback resulting.

Table 2 shows the paybacks found in the studies presented, as well as the characteristics of the residential buildings and the economic feasibility of the systems analysed.

Table 2. Paybacks for the implantation of rainwater harvesting systems in residential buildings.

\begin{tabular}{|c|c|c|c|}
\hline Reference & Feature & $\begin{array}{c}\text { Payback } \\
\text { (years) }\end{array}$ & Economic Feasibility \\
\hline \multirow{3}{*}[72]{} & Multi-family building block $\mathrm{A}$ & 2.4 & \multirow{2}{*}{ Feasible system } \\
\hline & Multi-family building block B & 5 & \\
\hline & Multi-family building block $C$ & - & There is no saving \\
\hline \multirow{6}{*}{ [99] } & Residence A with three inhabitants & 21.4 & \multirow{6}{*}{ Infeasible system } \\
\hline & Residence A with three inhabitants and $1 \%$ yearly rate & 25 & \\
\hline & Residence A with three inhabitants and $5 \%$ and $10 \%$ yearly rates & $>250$ & \\
\hline & Residence B with two inhabitants & 67.3 & \\
\hline & Residence B with two inhabitants and $1 \%$ yearly rate & 116 & \\
\hline & Residence B with two inhabitants and $5 \%$ and $10 \%$ yearly rates & $>250$ & \\
\hline \multirow{3}{*}[100]{} & Popular residence with water tariff of $\mathrm{R} \$ 1.99$ & $>20$ & \multirow{3}{*}{$\begin{array}{l}\text { Infeasible system } \\
\text { Feasible system }\end{array}$} \\
\hline & Medium standard residence with water tariff of $\mathrm{R} \$ 2.62$ & $>20$ & \\
\hline & High standard residence with water tariff of $\mathrm{R} \$ 3.53$ & 8.2 a 10.2 & \\
\hline [101] & Residence of $200 \mathrm{~m}^{2}$ with four inhabitants & 5.3 & Feasible system \\
\hline
\end{tabular}




\begin{tabular}{llll}
\hline \multirow{2}{*}{ 102] } & Minimum payback period & 1.5 & Feasible system in \\
& Maximum payback period & 30 & most cases \\
\hline \multirow{3}{*}[104]{} & Single-family residence with eight inhabitants (Rio Branco, Acre) & 24 & \\
& Single-family residence with five inhabitants (Rio Branco, Acre) & 27.1 & \multirow{2}{*}{ Infeasible system } \\
& Single-family residence with eight inhabitants (Belém, Pará) & 17.9 & \\
& Single-family residence with five inhabitants (Belém, Pará) & 20.1 & \\
\hline
\end{tabular}

According to Table 2, the payback periods of the studies presented ranged from 2.4 years to over 250 years. Among the factors that influence the economic feasibility of a rainwater harvesting system, the demand for non-potable water is directly related, since there is a minimum water tariff charged for a volume of $10 \mathrm{~m}^{3}$. That is, even if the consumption of potable water is less than $10 \mathrm{~m}^{3}$, there will be no reduction in the tariff charged for water consumption. Therefore, in residences in which consumption is less than this value, the implantation of a rainwater harvesting system is economically infeasible $[72,99,102,103]$. The water tariff charged also influences the economic feasibility of the system. The higher the tariff, the lower the payback period $[99,104]$.

In addition to studies on residential buildings, studies have also been found that analysed the economic feasibility of installing rainwater harvesting systems in commercial and public buildings. Fernandes, Neto, and Mattos [105] applied their feasibility study at the Federal University of Rio Grande do Norte, in Natal, Rio Grande do Norte. The economic feasibility of the system was defined by the net present value method. The authors found that the cistern scenario was more feasible over the 20 years analysed compared to the potable water scenario of the public system.

Marinoski and Ghisi [80] applied their study in SENAI educational institution, Technology Center in Automation and Computing, in Florianópolis, Santa Catarina. The building has two floors and a total constructed area equivalent to $5199.45 \mathrm{~m}^{2}$. The investment payback period of a rainwater harvesting system installation was 4 years and 10 months, which characterized the system as economically feasible.

Lage [97] evaluated the implementation of a rainwater harvesting system to wash vehicles at six concessionaires in Belo Horizonte, Minas Gerais. The payback for the system ranged from 75 to 143 months, equivalent to 6.3 and 11.9 years, respectively. As the useful life considered of the equipment and the system was of 15 years, the systems were judged economically feasible.

Mello, Pertel, and Souza [106] studied the economic feasibility of installing a rainwater harvesting system at the Paulo de Tarso Educational Institute, in Campos dos Goytacazes, Rio de Janeiro. The minimum attractiveness rate, the net present value, the internal rate of return, the simple payback, and the discounted payback were calculated. Two alternatives were considered: one with investments in the rainwater harvesting system (alternative 1) and the other remaining the potable water use project of the building and applying the investment value of the rainwater harvesting system in the savings account (alternative 2). In alternative 1, cash flow with and without financing was also considered for calculations of economic feasibility. The results showed that only alternative 1 without financing was economically feasible, with 9 years and 11 months for simple payback and 17 years and 8 months for discounted payback. Alternative 1 with financing was considered infeasible, because it presented negative net present value and internal rate of return lower than the minimum attractiveness rate. Alternative 2 also had negative net present value, and simple payback and discounted payback values were greater than 25 years.

Sánchez [107] analysed the economic feasibility of installing a rainwater harvesting system at the Polytechnic School of the Federal University of Bahia, in Salvador. In this study, the cost/benefit ratio, the internal rate of return, and the payback were calculated, considering a scenario in which $60 \%$ of the building's water demand will be served by the rainwater harvesting system and another scenario with attendance of $100 \%$ of the water demand. The paybacks were 14 month for the scenario with $60 \%$ and 6 months for the scenario with $100 \%$.

To evaluate the economic feasibility of a rainwater harvesting system at Severino Sombra University, in Vassouras, Rio de Janeiro, Souza et al. [108] considered different reservoir volumes and percentages of rainwater usage. Thereby, the authors obtained paybacks ranging from 3.8 years to 7.8 years. 
Table 3 shows the paybacks found in the studies presented, as well as the characteristics of commercial and public buildings and the economic feasibility of the analysed systems.

Table 3. Paybacks for the implantation of rainwater harvesting systems in commercial and public buildings.

\begin{tabular}{|c|c|c|c|}
\hline Reference & Feature & $\begin{array}{c}\text { Payback } \\
\text { (years) }\end{array}$ & $\begin{array}{l}\text { Economic } \\
\text { Feasibility }\end{array}$ \\
\hline [80] & Educational institution & 4.8 & Feasible system \\
\hline \multirow{6}{*}{ [97] } & Carbel Car Dealership & 6.3 & \multirow{6}{*}{ Feasible system } \\
\hline & Garra Car Dealership & 7.7 & \\
\hline & Catalão Car Dealership & 11.1 & \\
\hline & Misaki Car Dealership & 9.3 & \\
\hline & Valence Car Dealership & 6.8 & \\
\hline & Reauto Car Dealership & 11.9 & \\
\hline \multirow{6}{*}{ [106] } & $\begin{array}{l}\text { Educational institution, alternative } 1 \text {, unfunded cash flow, and } \\
\text { simple payback }\end{array}$ & 9.9 & Feasible system \\
\hline & $\begin{array}{l}\text { Educational institution, alternative 1, unfunded cash flow, and } \\
\text { discounted payback }\end{array}$ & 17.7 & \multirow{5}{*}{$\begin{array}{c}\text { Feasible system } \\
\text { Infeasible } \\
\text { system } \\
\text { Infeasible } \\
\text { system } \\
\text { Infeasible } \\
\text { system } \\
\text { Infeasible } \\
\text { system }\end{array}$} \\
\hline & $\begin{array}{l}\text { Institution of education, alternative } 1 \text {, cash flow with financing, and } \\
\text { simple payback }\end{array}$ & 16.3 & \\
\hline & $\begin{array}{l}\text { Educational institution, alternative } 1 \text {, cash flow with financing, and } \\
\text { discounted payback }\end{array}$ & 21 & \\
\hline & Educational institution, alternative 2, and simple payback & $>25$ & \\
\hline & Educational institution, alternative 2 , and discounted payback & $>25$ & \\
\hline \multirow{2}{*}{ [107] } & $\begin{array}{l}\text { Educational institution with replacement of } 60 \% \text { of the water } \\
\text { demand for rainwater }\end{array}$ & 1.2 & \multirow{2}{*}{ Feasible system } \\
\hline & $\begin{array}{l}\text { Educational institution with } 100 \% \text { substitution of water demand for } \\
\text { rainwater }\end{array}$ & 0.5 & \\
\hline \multirow{5}{*}{ [108] } & System with reservoir of $71 \mathrm{~m}^{3}$ and percentage of use of $10 \%$ & 7.8 & \multirow{5}{*}{ Feasible system } \\
\hline & System with reservoir of $142 \mathrm{~m}^{3}$ and percentage of use of $20 \%$ & 5.3 & \\
\hline & System with reservoir of $215 \mathrm{~m}^{3}$ and percentage of use of $30 \%$ & 4.5 & \\
\hline & System with reservoir of $285 \mathrm{~m}^{3}$ and percentage of use of $40 \%$ & 4 & \\
\hline & System with reservoir of $355 \mathrm{~m}^{3}$ and percentage of use of $50 \%$ & 3.8 & \\
\hline
\end{tabular}

Through Table 3, the paybacks for reported studies of commercial and public buildings ranged from 0.5 years to over 25 years. Compared with the results presented in Table 2, there is a greater economic feasibility in the implantation of rainwater harvesting systems in commercial and public buildings, which may be justified by the higher demand for non-potable water. Figure 5 shows the percentage frequencies of the investment return periods for the implantation of a rainwater harvesting system in the different typologies of buildings presented. 


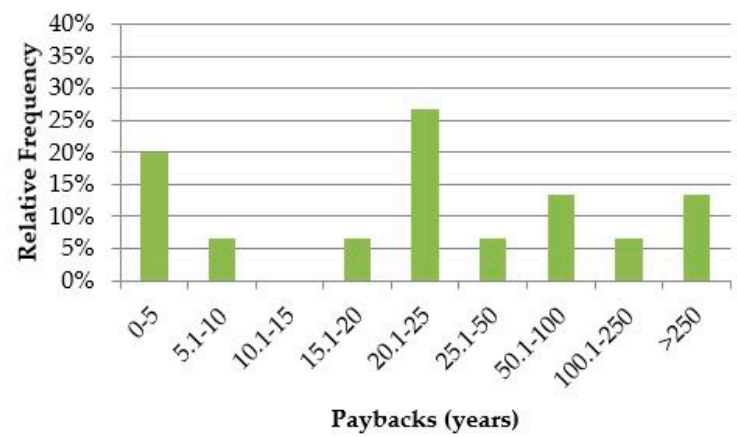

(a)

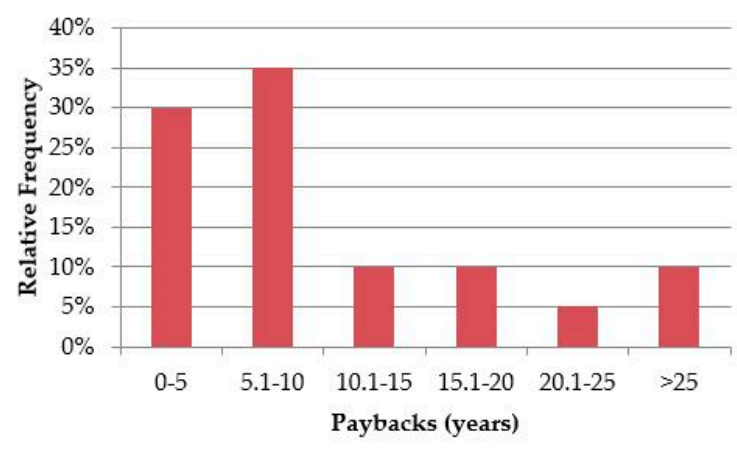

(b)

Figure 5. Percentage frequencies of the paybacks in (a) residential buildings and (b) commercial and public buildings.

In addition to economic feasibility, the rainwater usage has also environmental benefits. With the implementation of a rainwater harvesting system, the problems of urban drainage are reduced, since the system retains a significant part of the water that would flow through the streets and galleries. It would also reduce the use of potable water for non-potable uses, such as garden watering, car washing, and sidewalk washing [101,104].

The rainwater usage must also aim at preserving water resources, ensuring water security and encouraging environmentally sustainable actions [103,108]. Sánchez [107] also observed positive impacts on the drainage system, such as flood wave attenuation, the use of reservoirs as retention basins, and the improvement of the quality of rainwater sent to the hydrographic basin. According to Marinoski et al. [94], the environmental benefits obtained through potable water savings strategies are also influenced by the selection of the components of the system, since most of the energy incorporated in the strategies are related to the production of these components.

\subsection{Public Policies}

Considering the Brazilian government scenario, the rainwater harvesting is encouraged in several cities by legislation, either because it is a sustainable strategy or because it is a policy of access to water in arid cities.

Despite the encouragement and regulation in some cities, Brazil is still taking its first steps in this direction. The NBR 15.527/2007 Standard provides guidelines for designing rainwater harvesting systems for the roofs of buildings for use in non-potable purposes. Besides being outdated, since it does not provide guidelines for designing the system in a more modern way, the Brazilian norm does not cover guidelines for the safe use of rainwater in potable uses. This is important, since the Brazil has a semi-arid area where rainwater is the main water source for a great part of the year, and is used not only for toilets and cleaning but for cooking, shower, and personal hygiene. Besides, the sizing methods, parameters, and procedures are much outdated in relation to the international practices.

In Brazil, the "National Water Resources Plan" is the instrument that regulates and guides investments and actions related to water management in the country [109]. In this plan, the government water management programmes are detailed with a target up to 2020. Related to rainwater, the document only mentions the "One Million Cisterns" programme, which is a federal government investment launched in 2001 to provide access to water for families in the Brazilian semi-arid region by encouraging the construction of cisterns. Gomes et al. [19] evaluated the impact of the programme that installed, up to the time of this publication, 372 thousand cisterns. Another related government programme is "One Land Two Waters" programme $(\mathrm{P} 1+2)[110]$, also aimed at articulating the growth of the Brazilian semi-arid region and complementing the One Million Cisterns Programme. In this social programme, families of farmers receive technologies and training to capture and store rainwater for agricultural purposes, complementing the supply for human consumption purposes that are promoted by the One Million Cisterns Programme. 
In addition of mentioning the importance of abstraction in the Brazilian semi-arid region, "National Water Resources Plan" also mentions that the use of rainwater should be intensified, along with an increase in urban areas with vegetation cover, in order to prevent floods in cities. However, any goals or programmes to promote such actions were not quoted.

On July 8th of 1999, the Brazilian Association for Catchment, Management, and Utilization of Rainwater was founded. The objective of this association is to promote actions aimed at the rational and efficient use of rainwater in Brazil. Since its foundation, it has promoted symposiums and brought together researchers and professionals of the field to discuss the theme. It also has provided books and educational material, spreading information and concepts about the theme. Among the autarchies and institutions researched, it is considered the main Brazilian reference in the theme.

Also in the national scope, on 28 May 2015, a bill was proposed in the Federal Congress House that intends to make mandatory the implantation of rainwater use in buildings larger than $200 \mathrm{~m}^{2}$ (Federal Law Project \# 1750 of 2015). However, this legislation depends on the approval by political leaders to come into force.

However, municipal legislation is more restrictive in this regard, and some cities require implementation by their own legislation. Thus, a survey of the municipal legislations in the country that make the use of rainwater an obligatory practice, or that have some policy of rational use of water in buildings, was carried out. This demonstrates a concern on the part of municipalities regarding water governance. The result of this survey is observed in Figure 6.

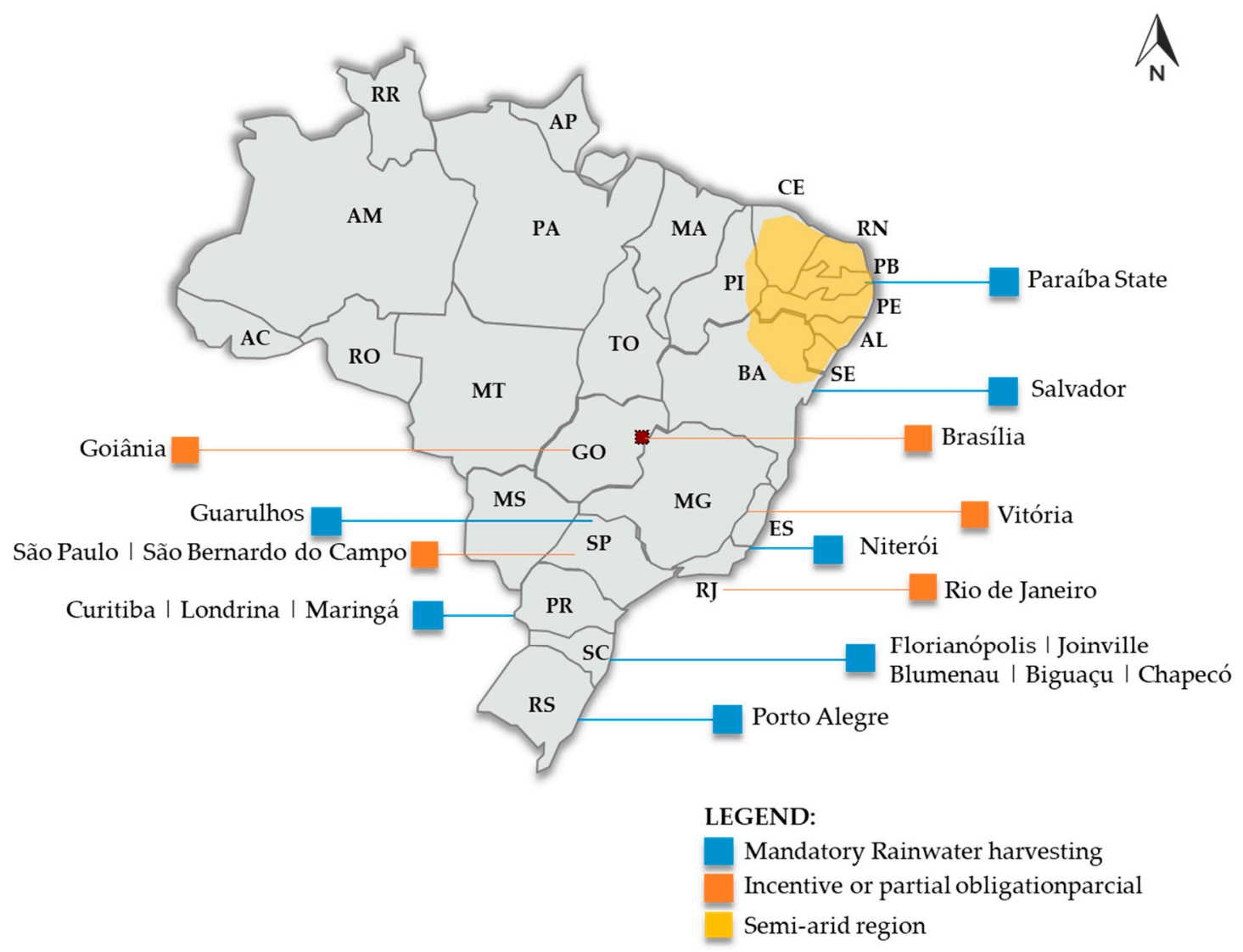

Figure 6. Map identifying cities with own legislation related to rainwater harvesting or water management.

It is possible to notice that many municipalities are concerned with the issue of exploitation, and most are not located in semiarid-Brazilian regions, which indicates an initiative related to sustainable development. Although it is present in some of the major Brazilian cities, such as São Paulo, Rio de Janeiro, Brasília and Porto Alegre, it is still present in only a small number of places compared to the all national territory. In addition, it is necessary to emphasize that the observed 
legislation is restricted to the dimensions of the buildings; for example, Florianópolis legislation requires use in constructions of more than $200 \mathrm{~m}^{2}$, while Blumenau city, only in constructions of more than $700 \mathrm{~m}^{2}$.

Some other types of legislation related to the use of rainwater have also been observed, as the legislations that improve sustainable practices in buildings and give bonuses increase the maximum constructed area allowed or apply discounts on the Urban Building and Land Tax, commonly called Green Tax (in Portuguese, "IPTU Verde"). It is a reality in some cities, as example of Florianópolis, Santa Catarina (Municipal Decree number 12,608 of 2014), Camboriú, Santa Catarina (Municipal law number 2544 of 2013), and Salvador, Bahia (Municipal Law number 8474 of 2013).

Among the legislations observed, the most important are the programmes implemented, particularly the cities of Curitiba-PR (Municipal Law \# 10855 of 2003), São Paulo (Municipal Law \# 14.018 of 2005), and Campinas (Municipal Law \# 12.474 of 2006). The programmes of these cities, called "Programme for Conservation and Rational Use of Water in Buildings", are more specific in relation to the subject and have several measures to instigate the reduction of water consumption and adoption of new water sources, as the use of rainwater. In these programmes, actions to improve the rational use of water are quoted, and for sure, rainwater harvesting is one of the most important practices cited and turned mandatory for every building greater than $200 \mathrm{~m}^{2}$.

Therefore, it is noted that the Brazilian legislation and public policies related to the rainwater harvesting in Brazil are still in an initial phase, and require more intensification by the authorities and leaders. Most of the initiatives are intended to progress semiarid region and supply families, but for the rest of the country rainwater is still not a fundamental part of the civil construction culture. Table 4 presents the list of legislations consulted.

Table 4. List of legislations consulted.

\begin{tabular}{ccccc}
\hline City & State & Type of Legislation & Law Number & Year \\
\hline Paraíba & PB & State law & No. 9130 & 2010 \\
Campinas & SP & Municipal law & No. 12,474 & 2006 \\
São Paulo & SP & Municipal law & No. 14,018 & 2005 \\
Curitiba & PR & Municipal law & No. 10,785 & 2003 \\
Florianópolis & SC & Municipal law & No. 482 & 2014 \\
Camboriú & SC & Municipal law & No. 2544 & 2013 \\
Salvador & BA & Municipal law & No. 8474 & 2013 \\
Florianópolis & SC & Municipal Decree & No. 12,608 & 2014 \\
Distrito Federal & DF & Municipal law & No. 3677 & 2005 \\
Goiânia & GO & Municipal law & No. 17,128 & 2010 \\
Rio de Janeiro & RJ & Municipal law & No. 3899 & 2005 \\
Rio de Janeiro & RJ & Municipal Decree & No. 23,940 & 2004 \\
Rio de Janeiro & RJ & Municipal law & No. 5279 & 2011 \\
Porto Alegre & RS & Municipal Decree & No. 16,305 & 2009 \\
Manaus & AM & Municipal law & No. 1192 & 2007 \\
João Pessoa & PB & Municipal law & No. 12,515 & 2013 \\
Londrina & PR & Municipal law & No. 11,381 & 2011 \\
Maringá & PR & Municipal law & No. 910 & 2008 \\
Vitória & ES & Municipal law & No. 7073 & 2007 \\
Joinville & SC & Municipal law & No. 220 & 2006 \\
Blumenau & SC & Municipal law & No. 691 & 2008 \\
Chapecó & SC & Municipal law & No. 324 & 2008 \\
\hline & & & &
\end{tabular}

\section{Conclusions}

This article aimed to present an analysis state of the art of rainwater harvesting in Brazil. The theme was analysed from the perspective of Brazilian scientific production, and studies were used to analyse the potential of saving potable water with regard to rainwater usage, the economic feasibility of the system, and the scope of public policies. Based on the evaluation developed on this article, the main conclusions are following: 
- Regarding the scientific production, it can be concluded that it follows the international pace. In both spheres, national and international, there has been a noticeable increase in number of studies in this area in the past five years.

- The studies that were focused on potable water savings show that the potential for saving water is intrinsic related to the type and use of the building, varying for each case. On a global view, the results of the reviewed works showed an average potential for potable water savings of $53 \%$ of the total water demand.

- The studies that were focused on economic feasibility analysed the payback and show that it varies accord to the type/use of the building. The major investment in the system consists in the installation phase, and the cistern represents the major coast. The payback was more attractive for commercial buildings if compared with residential buildings.

- The public policies about the theme are mainly focused on the rainwater harvesting to provide water supply for semi-arid region. On the other hand, there are laws turning rainwater harvesting mandatory in some cities and other laws that incentivise the practice, and both types of rules show an environmental concern by the municipal administrations. Despite the existence of legislation about rational water use in some cities, it is not present in a great part of the country.

- As a general conclusion, it is noted that both the potential for potable water savings and the economic feasibility were more noticeable in offices and public buildings in Brazil; however, there is no legislation or concern specifically about the regimentation of rationed water use in these types of buildings. Thus, public policies should improve and intensify the rainwater harvesting in these types of buildings, initially. Despite the economic benefits for public administration, and because of reduction water bills, rainwater harvesting in public buildings will serve as example for society, educating people and representing the social dimension of sustainability.

- It was observed that there are few studies that used the experimental process and/or innovative approach related to rainwater harvesting practice. This is probably due to the lack of investment for research.

Acknowledgments: Authors would like to thank CAPES, an agency of the Brazilian government for post-graduate education, for the financial support that allowed the development of this paper.

Conflicts of Interest: The authors declare no conflict of interest.

\section{References}

1. Bell, S. Renegotiating urban water. Prog. Plan. 2015, 96, 1-28.

2. Tassi, R. Efeito dos Microrreservatório de Lote Sobre a Macrodrenagem Urbana. Master's Thesis, [Effect of micro-reservoirs on Urban Macrodrainage], Federal University of Rio Grande do Sul, Porto Alegre, Brazil, 2002.

3. Tucci, C.E.M. Plano diretor de drenagem urbana: Princípios e concepção [Diretor plan of urban drainage: Principles and conception]. Rev. Brasileira Recur. Hídr. 1997, 2, 5-12.

4. Jiang, Y. China's water scarcity. J. Environ. Manag. 2009, 90, 3185-3196.

5. Hadadin, N.; Qaqish, M.; Akawwi, E.; Bdour, A. Water shortage in Jordan-Sustainable solutions. Desalination 2010, 250, 197-202.

6. Liu, J.; Wang, Y.; Yu, Z.; Cao, X.; Tian, L.; Sun, S.; Wu, P. A comprehensive analysis of blue water scarcity from the production, consumption, and water transfer perspectives. Ecol. Indic. 2017, 72, 870-880.

7. Vörösmarty, C.J.; Green, P.; Salisbury, J.; Lammers, R.B. Global water resources: Vulnerability from climate change and population growth. Science 2000, 289, 284-288.

8. Mukheibir, P. Water access, water scarcity, and climate change. Environ. Manag. 2010, 45, 1027-1039.

9. Vörösmarty, C.J.; Mcintyre, P.B.; Gessner, M.O.; Dudgeon, D.; Prusevich, A.; Green, P.; Glidden, S.; Bunn, S.E.; Sullivan, C.A.; Reidy Liermann, C.; et al. Global threats to human water security and river biodiversity. Nature 2010, 467, 555-561. 
10. Kummu, M.; Guillaume, J.H.A.; De Moel, H.; Eisner, S.; Flörke, M.; Porkka, M.; Siebert, S.; Veldkamp, T.I.E.; Ward, P.J. The world's road to water scarcity: Shortage and stress in the 20th century and pathways towards sustainability. Sci. Rep. 2016, 6, 327-345.

11. Associação Brasileira De Engenharia Sanitária E Ambiental-ABES. Perdas em Sistemas de Abastecimento de Água: Diagnóstico, Potencial de Ganhos Com Sua Redução e Propostas de Medidas Para o Efetivo Combate [Losses in Water Supply Systems, Potential Gains and Proposal of Actions for the Effective Mitigation]; ABES: São Paulo, Brazil, 2013.

12. National System of Sanitation Information-SNIS. Diagnóstico dos Serviços de Água e Esgoto 2015 [Diagnosis of Water and Sewerage Services]; SNIS: Brasília, Brazil, 2017.

13. Gomes, H.P. Sistemas de Saneamento: Eficiência Energética. [Sanitary Systems: Energy Efficiency], 1st ed.; Editora Universitária/UFPB: João Pessoa, Brazil, 2010.

14. Marlow, D.R.; Moglia, M.; Cook, S.; Beale, D.J. Towards sustainable urban water management: A critical reassessment. Water Res. 2013, 47, 7150-7161.

15. Stewart, R.A.; Willis, R.; Capati, B. Closing the loop on water planning: An integrated smart metering and web-based knowledge management system approach. In Proceedings of the 10th IWA International Conference on Instrumentation Control and Automation, Cairns, Australia, 2009.

16. Gleick, P.H. Roadmap for sustainable water resources southwestern North America. Water Int. 2010, 107, 21300-21305.

17. Carvalho, J.W.L.T. Configuração Urbana e Balanço Hídrico Com Aplicação do Modelo Aquacycle na Bacia Hidrográfica do Rio Belém-Curitiba/PR [Urban Configuration and Water Balance with Application of the Aquacycle Model in the Belém River Basin-Curitiba/PR]. Master's Thesis, Federal University of Paraná, Curitiba, Brazil, 2016.

18. Gomes, U.A.F.; Heller, L.; Pena, J.L.A. National Program for Large Scale Rainwater Harvesting: An Individual or Public Responsibility? Water Resour. Manag. 2012, 26, 2703-2714.

19. Pacheco, P.R.C.; Gomez, Y.D.; Oliveira, I.F.; Teixeira, L.C.G. A view of the legislative scenario for rainwater harvesting in Brazil. J. Clean. Prod. 2017, 141, 290-294.

20. May, S. Estudo de Viabilidade Para o Aproveitamento de Água de Chuva Para Consumo Não Potável em Edificações [Feasibility Study for the Use of Rainwater for Non-Potable Consumption in Buildings]. Master's Thesis, University of São Paulo, São Paulo, Brazil, 2004.

21. Bassanesi, K. Análise de Risco do Aproveitamento de Água de Chuva Para Uso Não Potável em Edificações [Risk Analysis of the Use of Rainwater for Non-Potable Use in Buildings]. Master's Thesis, Federal University of São Carlos, São Carlos, Brazil, 2014.

22. Santana, N.C.B. Qualidade Das Águas de Chuva em João Pessoa-PB: Estudo Comparativo Com Padrões de Qualidade Para Uso Residencial. [Rainwater Quality in João Pessoa-PB: Comparative Study with Quality Standards for Residential Use]. Master's Thesis, Federal University of Paraíba, João Pessoa, Brazil, 2012.

23. Bier, A.S. Avaliação Pós-Utilização de um Sistema de Aproveitamento de Água da Chuva: Estudo de Caso no Centro de Convivência na UPFRS [Post-Use Evaluation of a Rainwater Harvesting System: A Case Study at the UPFRS Communal Center]. Master's Thesis, Foundation University of Passo Fundo, Passo Fundo, Brazil, 2013.

24. Lopes, G.B. Estudo da Viabilidade do Aproveitamento de Água de Chuva Para Fins Não Potáveis na Universidade Federal de Uberlândia/MG [Study of the Feasibility of the Use of Rainwater for Non-Potable Purposes at the Federal University of Uberlândia/MG]. Master's Thesis, Federal University of Uberlândia, Uberlândia, Brazil, 2012.

25. Corrêa, T.H.P. Avaliação Quali-quantitativa do Fitoplancton Presente em Reservatório de Sistema de Aproveitamento de Água Pluvial Para Irrigação [Qualitative and Quantitative Evaluation of Phytoplankton Present in Irrigation Pluvial Water Utilization System Reservoir]. Master's Thesis, Federal University of São Carlos, São Carlos, Brazil, 2012.

26. May, S. Caracterização, Tratamento e Reúso de Águas Cinzas e Aproveitamento de Águas Pluviais em Edificações [Characterization, Treatment and Reuse of Greywater and Use of Rainwater in Buildings]. Ph.D. Thesis, Univeristy of São Paulo, São Paulo, Brazil, 2009.

27. Menezes, E.C.P. Avaliação da Qualidade da Água da Chuva em Sistema de Aproveitamento de Água de Chuva Implantado na Universidade Federal do Pará [Evaluation of Rainwater Quality in a Rainwater 
Harvesting System Implemented at the Federal University of Pará]. Master's Thesis, Federal University of Pará, Belém, Brazil, 2016.

28. Giacchini, M. Estudo quali-quantitativo do Aproveitamento da Água de Chuva no Contexto da Sustentabilidade dos Recursos Hídricos [Qualitative and Quantitative Study of the Utilization of Rainwater in the Context of the Sustainability of Water Resources]. Master's Thesis, Federal University of Paraná, Curitiba, Brazil, 2010.

29. Pires, J.D.T.S. Reúso de Água Cinza e Aproveitamento da Água de Chuva Como Fontes Alternativas em Propriedades Rurais [Reuse of Greywater and Use of Rainwater as Alternative Sources in Rural Properties]. Master's Thesis, Federal University of Santa Catarina, Florianópolis, Brazil, 2012.

30. Amaral, X.S. Avaliação de Sistemas de Tratamento de Esgoto e Aproveitamento de Água de Chuva em Unidades Educacionais [Evaluation of Sewage Treatment Systems and Use of Rainwater in Educational Buildings]. Master's Thesis, Federal University of Rio Grande do Norte, Natal, Brazil, 2015.

31. Nunes, J.G. Análise da Concepção e Comportamento do Sistema de Aproveitamento de Água de Chuva em Operação na UFMT, Campus Cuiabá [Analysis of the Design and Behaviour of the Rainwater Harvesting System in Operation at UFMT, Campus Cuiabá]. Master's Thesis, Federal University of Mato Grosso, Cuiabá, Brazil, 2016.

32. Silva, M.M.C. O potencial de Captação e Abastecimento de Água Pluvial na Comunidade Vila de Lindóia-Município de Itacoatiara [The Potential for Collecting and Supplying Rainwater in the Community of Vila de Lindóia-City of Itacoatiara]. Master's Thesis, Federal University of Pará, Belém, Brazil, 2015.

33. Oliveira, C.L. Aproveitamento de Água de Chuva Para Usos Não-Potáveis no Município do Rio de Janeiro [Rainwater Harvesting for Non-Potable Uses in the City of Rio de Janeiro]. Master's Thesis, Federal University of Rio de Janeiro, Rio de Janeiro, Brazil, 2007.

34. Guedes, T.L. Tratamento de Água de Chuva Através de Microfiltração Tangencial [Treatment of Rainwater through Tangential Microfiltration]. Master's Thesis, Federal University of Santa Catarina, Florianópolis, Brazil, 2012.

35. Bastos, F.P. Tratamento de Água de Chuva Através de Filtração Lenta e Desinfecção UV [Rainwater Treatment through Slow Filtration and UV Disinfection]. Master's Thesis, Federal University of Espírito Santo, Vitória, Brazil, 2007.

36. Dias, I.C.S. Estudo da Viabilidade Técnica, Econômica e Social do Aproveitamento de Água de Chuva em Residências na Cidade de João Pessoa [Study of the Technical, Economic and Social Viability of the Use of Rainwater in Residences in the City of João Pessoa]. Master's Thesis, Federal University of Paraíba, João Pessoa, Brazil, 2007. (In Portuguese).

37. Geraldi, M.S. Influência do Tamanho de Séries Temporais de Precipitação em Simulações de Sistemas de Aproveitamento de Água Pluvial em Edificações [Influence of the Rainfall Time Series Length on Simulations of Rainwater Harvesting Systems in Buildings]. Master's Thesis, Federal University of Santa Catarina, Florianópolis, Brazil, 2017.

38. Neto, J.E.D.P. Modelo Sustentável de Aproveitamento Pluvial: Uso Racional dos Recursos Hídricos Considerando Oferta e Demanda Para Dimensionamento de um Reservatório Ótimo. Estudo de Caso Para o Município de Poços de Caldas-MG [Sustainable Model for Rainfall Utilization: Rational Use of Water Resources Considering Supply and Demand to Design an Optimal Reservoir. Case Study for the Municipality of Poços de Caldas-MG]. Master's Thesis, Federal University of Alfenas, Alfenas, Brazil, 2017.

39. Dornelles, F. Aproveitamento de Água de Chuva no Meio Urbano [Rainwater Harvesting in Urban Areas]. Ph.D. Thesis, Federal University of Rio Grande do Sul, Porto Alegre, Brazil, 2012.

40. Sampaio, F.E.V. Análise da Viabilidade de Implantação e Pré-Dimensionamento de Sistemas de Aproveitamento de Água Pluvial em Centros Urbanos [Analysis of the Feasibility of Implantation and Pre-Dimensioning of Systems for Rainwater Harvesting in Urban Centers]. Master's Thesis, University of Brasilia, Brasília, Brazil, 2013.

41. Coscarelli, A.P.F. Aproveitamento da Água de Chuva Para Fins Não Potáveis em Uma Atividade Industrial: Estudo de Caso de Uma Edificação a Ser Construída, Rio de Janeiro, RJ [Rainwater Harvesting for Non-Potable Purposes in an Industrial Activity: A Case Study of a New Building in Rio de Janeiro, RJ]. Master's Thesis, State University of Rio de Janeiro, Rio de Janeiro, Brazil, 2010. 
42. Andrade, V.H. Ferramenta Gráfica Para o Dimensionamento de Reservatórios para Aproveitamento de Águas Pluviais. Estudo de Caso na Região Norte de Rondônia [Graphical Tool to Size Rainwater Harveting Tanks. Case Study in the North Region of Rondônia]. Master's Thesis, Federal Technology University of Paraná, Curitiba, Brazil, 2017.

43. Rocha, V.L. Validação de um Algoritmo Para Avaliação do Potencial de Economia de Água Potável e Dimensionamento de Reservatórios de Sistemas de Aproveitamento de Água Pluvial em Edificações [Validation of an Algorithm to Evaluate the Potential for Potable Water Savings and Designing Tanks for the Utilization of Rainwater in Buildings]. Master's Thesis, Federal University of Santa Catarina, Florianópolis, Brazil, 2009.

44. Perius, C.F. Variáveis de Projeto e Sua Influência no Desempenho e Dimensionamento de Reservatórios de Aproveitamento de Água da Chuva [Project Variables and Their Influence on the Performance and Design of Rainwater Harvesting Reservoirs]. Master's Thesis, Federal University of Santa Maria, Santa Maria, Brazil, 2016.

45. Vercosa, D.K.D.S. Análise dos Métodos de Dimensionamento de Reservatórios de Captação de Águas Pluviais em Edificações no Município de Niterói [Analysis of the Methods of Sizing Rainwater Harvesting Tanks in Buildings in the City of Niterói]. Master's Thesis, Federal Univeristy Fluminense, Niterói, Brazil, 2014.

46. Cruz, W.M. Aproveitamento de Água Pluvial Para Fins Não Potáveis em Edificações Residenciais: Caso de Estudo em Rio Branco/AC [Rainwater Harvesting for Non-Potable Purposes in Residential Buildings: Case Study in Rio Branco/AC]. Master's Thesis, Federal University of Pará Belém, Brazil, 2014.

47. Chaib, E.B.D. Avaliação de Estratégias Para a Redução do Consumo de Água de Abastecimento Como Meio de Diminuição da Pressão Sobre os Recursos Hídricos [Evaluation of Strategies to Reduce the Water Consumption as a Means of Reducing the Pressure on Water Resources]. Ph.D. Thesis, Federal University of Minas Gerais, Belo Horizonte, Brazil, 2016.

48. Souza, T.J. Potencial de Aproveitamento de Água de Chuva no Meio Urbano: O Caso de Campina Grande-PB [Potential for Rainwater Harvesting in the Urban Environment: The Case of Campina Grande-PB]. Master's Thesis, Federal University of Campina Grande, Campina Grande, Brazil, 2015.

49. Beltrão, D.H. Medidas Para Conservação de Água em Habitações de Interesse Social na Cidade do Recife, PE [Actions for Water Conservation in Social Housing in the City of Recife, PE]. Master's Thesis, University of Pernambuco, Recife, Brazil, 2014.

50. Pacheco, G.C.R. Análise de Opções Reais Como Método de Avaliação Econômica de Sistemas Prediais de Aproveitamento de Água Pluvial [Analysis of Real Options as a Method of Economic Evaluation of Rainwater Harvesting Systems]. Master's Thesis, Federal University of Goiás, Goiânia, Brazil, 2016.

51. Gomez, Y.D. Aproveitamento de Água da Chuva Residencial: Efeito de Políticas de Incentivos e Condições de Consumo Sobre a Viabilidade Econômica [Rainwater Harvesting in Houses: Effect of Incentive Policies and Consumption Conditions on Economic Viability]. Master's Thesis, Federal University of Pará, Belém, Brazil, 2017.

52. Santos, C.M.M. Proposição de Sistema de Aproveitamento de Água de Chuva Para o Campus Campina Grande do IFPB: Estudo da Viabilidade Econômica [Proposal of a Rainwater Harvesting System for the Campina Grande Campus of the IFPB: Economic Feasibility Study]. Master's Thesis, Federal University of Paraíba, João Pessoa, Brazil, 2012.

53. Gois, E.H.B. Estudo de Caso: Minimização e Reúso de Água em Shopping Center da Região Sul do Brasil [Case Study: Minimization and Reuse of Water in a Shopping Centre in Southern Brazil]. Master's Thesis, Federal Technology University of Paraná, Curitiba, Brazil, 2015.

54. Marinoski, A.K. Método Para Avaliação de Viabilidade Ambiental e Econômica de Sistemas de Aproveitamento de Água Pluvial [Method for Evaluating the Environmental and Economic Feasibility of Rainwater Harvesting Systems]. Master's Thesis, Federal University of Santa Catarina, Florianópolis, Brazil, 2010.

55. Leão, C.L.P. Estimativa da Correção do Coeficiente de Retorno de Esgoto Sanitário em Habitações Com Sistemas de Aproveitamento de Água Pluvial: Estudo de Caso da Cidade de Bauru (SP) [Estimation of the Coefficient of Return of Sanitary Sewage in Dwellings with Rainwater Harvesting Systems: A Case Study from the City of Bauru (SP)]. Master's Thesis, State University of Paulista Júlio de Mesquita Filho/Bauru, Bauru, Brazil, 2015. 
56. Ribeiro, A.K.M. Método Para Avaliação do Impacto Ambiental da Implantação de Sistemas Integrados de Aproveitamento de Água Pluvial e Água Cinza em Residências Unifamiliares a Partir da Análise do Ciclo de Vida [Method for Evaluating the Environmental Impact of the Implementation of Integrated Systems for the Rainwater Harvesting and Greywater Reuse in Single-Family Based on LCA]. Ph.D. Thesis, Federal University of Santa Catarina, Florianópolis, Brazil, 2015.

57. Hentges, S.C. Efeito de Reservatório de Aproveitamento de Agua da Chuva Sobre Redes De Drenagem Pluvial [Effect of Rainwater Harvesting Tanks on Urban Drainage Networks]. Master's Thesis, Federal University of Santa Maria, Santa Maria, Brazil, 2013.

58. Teston, A. Impacto do Aproveitamento de Água da Chuva na Drenagem: Estudo de Caso de um Condomínio Horizontal em Curitiba-PR [Impact of Rainwater Harvesting on Drainage: Case Study of a Horizontal Condominium in Curitiba-PR]. Master's Thesis, Federal University Paraná, Curitiba, Brazil, 2015.

59. Klein, L.B. Controle Qualitativo e Quantitativo do Escoamento Pluvial em Diferentes Tipos de Coberturas [Qualitative and Quantitative Control of Rainfall in Different Types of Roofs]. Master's Thesis, Federal University of Santa Catarina, Florianópolis, Brazil, 2017.

60. Teixeira, P.C. Qualidade da Água Drenada por Coberturas Verdes Para Fins de Aproveitamento em Edifício [Water Quality Drained by Green Roofs for Use in Buildings]. Master's Thesis, State University of Campinas, Campinas, Brazil, 2013.

61. Rocha, B.C.C.M. Avaliação do Desempenho do Sistema de Descarte de Água de Chuva Coletada em Coberturas de Três Diferentes Tipos de Materiais [Evaluation of the Performance of the Rainwater Disposal System Collected in Roofs of Three Different Types of Materials]. Master's Thesis, Federal University of Goiás, Goiânia, Brazil, 2010.

62. Oliveira, S.L. Aproveitamento de Água Pluvial em Edificações Residenciais Urbanas [Rainwater Harvesting in Urban Residential Buildings]. Master's Thesis, FUMEC, Belo Horizonte, Brazil, 2016.

63. Alves, V.O. Aproveitamento de Água de Chuva Para Consumo Humano em Áreas Rurais de Municípios Isolados Pela Seca no Estado do Amazonas [Utilization of Rainwater for Human Consumption in Rural Areas of Isolated Cities Due to Drought in the State of Amazonas]. Master's Thesis, Universidade Federal do Pará, Belém, Brazil, 2015.

64. Hafner, A.V. Conservação e Reúso de Água em Edificações-Experiências Nacionais e Internacionais [Water Conservation and Reuse in Buildings-National and International Experiences]. Master's Thesis, Federal University of Rio de Janeiro, Rio de Janeiro, Brazil, 2007.

65. Ghimire, S.R.; Jonhston, J.M.; Ingwersen, W.W.; Sojka, S. Life cycle assessment of a commercial rainwater harvesting system compared with a municipal water supply system. J. Clean. Prod. 2017, 151, 74-86.

66. Ghisi, E. Potential for potable water savings by using rainwater in the residential sector of Brazil. Build. Environ. 2006, 41, 1544-1550.

67. Ghisi, E.; Montibeller, A.; Schmidt, R.W. Potential for potable water savings by using rainwater: An analysis over 62 cities in southern Brazil. Build. Environ. 2006, 41, 204-210.

68. Ghisi, E.; Cardoso, K.A.; Rupp, R.F. Short-term versus long-term rainfall time series in the assessment of potable water savings by using rainwater in houses. J. Environ. Manag. 2012, 100, 109-119.

69. Souza, E.L.; Ghisi, E. Potable water savings by using rainwater for non-potable uses in houses. Water 2012, 4, 607-628.

70. Ghisi, E.; Rupp, R.F.; Triska, Y. Comparing indicators to rank strategies to save potable water in buildings. Resour. Conserv. Recycl. 2014, 87, 137-144.

71. Lopes, A.C.; Rupp, R.F.; Ghisi, E. Assessment of the potential for potable water savings by using rainwater in houses in southern Brazil. Water Sci. Technol. Water Supply 2016, 16, 533-541.

72. Ghisi, E.; Ferreira, D.F. Potential for potable water savings by using rainwater and greywater in a multi-storey residential building in southern Brazil. Build. Environ. 2007, 42, 2512-2522.

73. Kammers, P.C. Projeto de Instalações Hidráulicas Com Aproveitamento de Água Pluvial em um Edifício Residencial Multifamiliar Localizado em Florianópolis [Project of Hydraulic Installations with Use of Rainwater in a Multi-Family Building Located in Florianópolis]; Federal University of Santa Catarina: Florianópolis, Brazil, 2007.

74. Senger, V. Análise de Viabilidade Para Aproveitamento de Água de Chuva e Reuso de Água em Residência Unifamiliar: Estudo de Caso em Panambi-RS [Feasibility Analysis for Rainwater Harvesting and Water Reuse in a 
Single-Family Home: A Case Study in Panambi-RS]; Federal University of Santa Catarina: Florianópolis, Brazil, 2007.

75. Coelho, G.M. Avaliação Dos Usos Finais de Água em Residências Unifamiliares Localizadas em Blumenau-SC [Evaluation of Water End-Uses in Single-Family Homes Located in Blumenau-SC]; Federal University of Santa Catarina: Florianópolis, Brazil, 2008.

76. Barreto, D. Perfil do consumo residencial e usos finais de água [Profile of residential consumption and water end-uses]. Ambient. Construído 2008, 8, 23-40.

77. Marinoski, A.K.; Vieira, A.S.; Silva, A.S.; Ghisi, E. Water end-uses in low-income houses in Southern Brazil. Water 2014, 6, 1985-1999.

78. Meinchein, D.L. Potencial de Economia de Água Potável Através do Aproveitamento de Água Pluvial em Uma Residência Unifamiliar Localizada em São José-SC [Potential for Potable Water Savings through Rainwater Harvesting in a Single-Family Residence Located in São José-SC]; Federal University of Santa Catarina: Florianópolis, Brazil, 2015.

79. Dalsenter, M.E. Estudo do Potencial de Economia de Água Potável Por Meio do Aproveitamento de Água Pluvial em um Condominio Residencial Multifamiliar Localizado em Florianópolis-SC [Potential for Potable Water Savings through the Use of Rainwater in a Multi-Family Building Located in Florianópolis-SC]; Federal University of Santa Catarina: Florianópolis, Brazil, 2016.

80. Marinoski, A.K.; Ghisi, E. Aproveitamento de água pluvial para usos não potáveis em instituição de ensino: Estudo de caso em Florianópolis-SC [Rainwater harvesting for non-potable uses in schools: A case study in Florianópolis-SC]. Ambient. Cosntruído 2008, 8, 67-84.

81. Fasola, G.B.; Ghisi, E.; Marinoski, A.K.; Borinelli, J.B. Potencial de economia de água em duas escolas em Florianópolis, SC [Potential for potable water savings in two schools in Florianópolis, SC]. Ambient. Construído 2011, 11, 65-78.

82. Nascimento, E.A.A.; Sant 'Ana, D. Caracterização dos usos-finais do consumo de água em edificações do Setor Hoteleiro de Brasília [Characterization of water end-uses in in hotels in Brasília]. Revista de Arquitetura da IMED 2014, 3 (2), 156-167.

83. Proença, L.C.; Ghisi, E. Water end-uses in Brazilian office buildings. Resour. Conserv. Recycl. 2010, 54, 489500.

84. Kammers, P.C.; Ghisi, E. Usos finais de água em edifícios públicos localizados em Florianópolis-SC [End-uses of water in public buildings located in Florianópolis-SC]. Ambient. Construído 2006, 6, 75-90.

85. Teston, A.; Colasio, B.M.; Ghisi, E. State of the Art on Water Savings in Buildings in Brazil: A Literature Review. In Frontiers in Civil Engineering; Ghisi, E., Ed.; Bentham Science Publishers: Sharjah, United Arab Emirates, 2017; Volume 2, pp. 3-64.

86. Geraldi, M.S.; Ghisi, E. Influence of the length of rainfall time series on rainwater harvesting systems: A case study in Berlin. Resour. Conserv. Recycl. 2017, 125, 169-180.

87. Bezerra, S.M.C.; Christan, P.; Teixeira, C.A.; Farahbakhsh, K. Dimensionamento de reservatório para aproveitamento de água de chuva: Comparação entre métodos da ABNT NBR 15527:2007 e Decreto Municipal 293/2006 de Curitiba, PR [Sizing Rainwater harvesting tanks: Comparison between methods of ABNT NBR 15527: 2007 and Municipal Decree 293/2006 of Curitiba, PR]. Ambient. Construído 2010, 6, 7590.

88. Ghisi, E.; Tavares, D.F.; Rocha, V.L. Rainwater harvesting in petrol stations in Brasília: Potential for potable water savings and investment feasibility analysis. Resour. Conserv. Recycl. 2009, 54, 79-85.

89. Ghisi, E. Parameters Influencing the Sizing of Rainwater Tanks. Water Resour. Manag. 2010, 24, 2381-2403.

90. Cordova, M.M.; Ghisi, E. Analysis of potable water saving using behavioural models. Water Conserv. 2011, 1, 89-104.

91. Ghisi, E.; Cordova, M.M. Netuno 4. Programa Computacional [Netuno 4. Computer Programme]. Federal University of Santa Catarina. Available online: http://www.labeee.ufsc.br/ (accessed on 20 September 2017).

92. Ghisi, E.; Bressan, D.L; Martini, M. Rainwater tank capacity and potential for potable water savings by using rainwater in the residential sector of southeastern Brazil. Build. Environ. 2007, 42, 1654-1666.

93. Vill, M.R. Aproveitamento de Água Pluvial Para Fins Não Potáveis: Viabilidade Econômica Para as Cidades de Santana do Ipanema, Florianópolis e Santos [Rainwater Harvesting for Non-Potable Purposes: Economic Viability for the Cities of Santana do Ipanema, Florianópolis and Santos]; Engenharia Civil. Federal University of Santa Catarina: Florianópolis, Brazil, 2010. 
94. Marinoski, A.K.; Rupp, R.F.; Ghisi, E. Environmental benefit analysis of strategies for potable water savings in residential buildings. J. Environ. Manag. 2018, 206, 28-39.

95. Salla, M.R.; Lopes, G.B.; Pereira, C.E.; Neto, J.C.M.; Pinheiro, A.M. Viabilidade técnica de implantação de sistema de aproveitamento de água pluvial para fins não potáveis em universidade [Technical feasibility of implantation of rainwater harvesting system for non-potable purposes in a university]. Ambient. Construído 2013, 13, 167-181.

96. Silva, A.S.; Ghisi, E. Uncertainty analysis of daily potable water demand on the performance evaluation of rainwater harvesting systems in residential buildings. J. Environ. Manag. 2016, 180, 82-93.

97. Lage, E.S. Aproveitamento de Água Pluvial em Concessionárias de Veículos na Cidade de Belo Horizonte: Potencial de Economia de Água Potável e Estudo de Viabilidade Econômica [Rainwater Harvesting in Car Dealerships in the City of Belo Horizonte: Potential for Potable Water Savings and Economic Feasibility Study]. Master's Thesis, Santa Catarina Federal University, Florianópolis, Brazil, 2010.

98. Ilha, M.S.O.; Campos, M.A.S. Qualidade de investimentos no uso de água pluvial: Particles Swarm Optimization para a maximização do valor presente líquido [Quality of investments in the use of rainwater: Particles Swarm Optimization for the maximization of the net present value]. Eng. Sanit. Ambient. 2014, 19, 373-382.

99. Ghisi, E.; Oliveira, S.M. Potential for potable water savings by combining the use of rainwater and greywater in houses in southern Brazil. Build. Environ. 2007, 42, 1731-1742.

100. Júnior, G.B.A.; Dias, I.C.S.; Gadelha, C.L.M. Viabilidade econômica e aceitação social do aproveitamento de águas pluviais em residências na cidade de João Pessoa [Economic viability and social acceptance of rainwater harvesting in residences in the city of João Pessoa]. Ambient. Construído 2008, 8, 85-98.

101. Carvalho, R.S. Potencial econômico do aproveitamento de águas pluviais: Análise da implantação de um sistema para a região urbana de Londrina [Economic potential of the use of rainwater: Analysis of the implementation of a system for the urban region of Londrina]. Master's Thesis, Paraná Federal University, Apucarana, Brazil, 2010.

102. Ghisi, E.; Schondermark, P.N. Investment Feasibility Analysis of Rainwater Use in Residences. Water Resour. Manag. 2013, 27, 2555-2576.

103. Berwanger, H.; Ghisi, E. Investment feasibility analysis of rainwater harvesting in the city of Itapiranga, Brazil. Int. J. Sustain. Hum. Dev. 2014, 2, 104-114.

104. Cruz, W.M.; Blanco, C.J.C. Aproveitamento de água pluvial para fins não potáveis residenciais em Rio Branco-AC [Rainwater harvesting for non-potable residential purposes in Rio Branco-AC]. Perspect. Online Exatas Eng. 2017, 17, 12-24.

105. Fernandes, D.R.M.; Neto, V.B.M.; Mattos, K.M.C. Viabilidade Econômica do Uso da Água da Chuva: Um Estudo de Caso da Implantação de Cisterna na UFRN/RN [Economic Viability of Rainwater Harvesting: A Case Study of the Implantation of a Cistern in UFRN/RN]; Enegep, XXVII Encontro Nacional de Engenharia de Produção: Foz do Iguaçu, Brazil, 2007.

106. Mello, M.; Pertel, M.; Souza, F.P. Análise de viabilidade econômica: Um estudo de aproveitamento da água de chuva no Instituto Educacional Paulo de Tarso-Campos, RJ [Economic feasibility analysis: A study of the rainwater harvesting in the Paulo de Tarso Educational Institute-Campos, RJ]. Perspect. Online Exatas Eng. 2014, 4, 31-50.

107. Sánchez, A.S. Aproveitamento de Águas Pluviais na Escola Politécnica da Universidade Federal da Bahia [Rainwater Harvesting at the Polytechnic School of the Federal University of Bahia]. Master's Thesis, Bahia Federal University, Salvador, Brazil, 2014.

108. Souza, J.F.; Neto, M.R.F.; Souza, M.A.S.; Veneu, D.M. Aproveitamento de água de chuva para usos não potáveis na Universidade Severino Sombra [Rainwater harvesting for non-potable uses at Severino Sombra University]. Rev. Eletrôn. Teccen 2016, 9, 35-46.

109. Brasil. Plano Nacional de Recursos Hídricos. Diretrizes: Volume 3 [National Plan for Water Resources. Directions: Volume 3]; Ministério do Meio Ambiente, Secretaria de Recursos Hídricos: Brasília, Brazil,2006.

110. Gnadlinger, J. O Programa Uma Terra Duas Águas (P1 + 2) e a Captação e o Manejo de Água da Chuva [The One Land Two Waters Sources Programme $(P 1+2)$ and Rainwater Harvesting and Management]; Simpósio Brasileiro de Captação e Manejo de Água de Chuva: Teresina, Piauí, Brasil. 2005.

(c) 2018 by the authors; Licensee MDPI, Basel, Switzerland. This article is an open access article distributed under the terms and conditions of the Creative Commons Attribution (CC BY) license (http://creativecommons.org/licenses/by/4.0/). 